\title{
A COMPARATIVE STUDY ON PROPHYLACTIC ANTIBIOTIC BETWEEN ITS SHORT TERM USE AND TRADITIONAL LONG TERM USE IN ELECTIVE SURGERY- STUDY OF 100 CASES
}

\author{
AL MAMUN A ${ }^{1}$, MUSTAFA ASMF $^{2}$, HASAN M$^{3}$, ALAUDDIN $^{4}$, RAHMAN $^{5}$, HAQUE AHMA $^{6}$
}

\begin{abstract}
Context: Antibiotic prophylaxis has profound role in minimizing postoperative wound infection in elective surgery.

Methods: A prospective study was designed and done in different surgical units of Mymensingh Medical College Hospital, Mymensingh, from January to December 2005. Patients admitted within that period for elective surgical operations in different surgical units of Mymensingh Medical College Hospital were included in this study. However, among the patients, those who were suffering from severe malnutrition, systemic disease like diabetes mellitus, uraemia, jaundice, patients of malignancy or patients receiving steroid/cytotoxic therapy were not included in this study. In this study, 100 patients have been selected randomly irrespective of their age and sex. Half of the participants (50 cases) received three dose short term antibiotic prophylaxis (designated as short term group) and the rest of half (50 cases) received long term antibiotics for 7 days (designated as long term group)
\end{abstract}

Result: In short-term antibiotic prophylaxis group, there were 5 postoperative wound infections of the 50 patients for an overall infections rate of $10 \%$. In long-term antibiotic prophylaxis group, there were 6 wound infections of the 50 patients for an overall infection rate of $12 \%$. Chi-squired test showed there is no difference between the two group of infection rate $(p<0.001)$. The duration of hospital stay in most of the cases (45 cases) was less than 7 days in short term group and in most of the cases (47 cases) in long duration antibiotic prophylaxis group was more than 7 days.

Conclusion: This study showed that short term three doses of prophylactic antibiotic is as effective as long-term use of antibiotics traditionally practiced in many centres of our country in elective surgery.

Key words: Elective surgery, use of prophylactic antibiotic, short term, long term, wound infection, hospital stay.

J Dhaka Med Coll. 2012; 21(1) : 60-65.

\section{Introduction:}

The range of surgery now practiced owes much to rational antibiotic use ${ }^{1}$. Prophylactic antibiotic are given empirically during or prior to surgery to exert their action when local wound defenses are at their least (the decisive period). It has been shown that for many contaminated and clean-contaminated procedures the postoperative infection rate can be decreased by use of appropriate prophylactic antibiotic given prior to surgery ${ }^{1-3}$. Antibiotic prophylaxis should be used only when contamination of a wound is expected or when operations of a contaminated site may lead to bacteraemia. It is not required for clean procedures except when an implant or vascular graft is inserted, in valvular heart disease to prevent infective endocarditis, during

1. Dr. Mohammad Abdullah Al Mamun, Assistant Professor, Department of Surgery, Shaheed Suhrawardy Medical College, Dhaka.

2. Dr. Abu Sayeed Md. Feroz Mustafa, Consultant Surgeon, Munshiganj Sadar Hospital, Munshigonj.

3. Dr. Mahmud Hasan, Associate Professor, Department of Surgery, Shaheed Suhrawardy Medical College, Dhaka.

4. Dr. Md. Alauddin, Orthopaedics Consultant, Gazipur Sadar Hospital, Gazipur.

5. Dr. Atiar Rahman, Assistant Professor, Department of Surgery, Dhaka Medical College Hospital, Dhaka.

6. Dr. Abdul Hasnat Muhammad Afzalul Haque, Assistant Registrar, Department of Surgery, DMCH, Dhaka Correspondence : Dr. Mohammad Abdullah Al Mamun, Assistant Professor, Department of Surgery, Shaheed Suhrawardy Medical College, Dhaka. Cell Phone: +8801711623285, Email: mamun1973@gmail.com 
emergency surgery in a patient with preexisting or recently active infection or if an infection would be very severe and have life threatening consequences ${ }^{4}$. The antibiotic should, whenever possible, be bactericidal in nature with high tissue penetration ability and low toxicity ${ }^{5}$. Antibiotics should be chosen to cover relevant organisms. The agent to be used should be decided upon after discussion with the microbiologist regarding likely contaminants and local resistance patterns ${ }^{6}$. Antibiotic prophylaxis is not an alternative to good surgical practice including strict aseptic technique and is indicated when the risk of infection is high (clean-contaminated and dirty operations) or the results of infection if it occurs are serious ${ }^{5}$. The situations in surgical practice when antibiotic prophylaxis is indicated because of proven benefit are breast surgery, gastro esophageal surgery, biliary surgery, colorectal surgery, acute appendicitis, orthopedic surgery, endoscopic urological surgery, vascular surgery etc ${ }^{5}$.Prophylactic antibiotic can be administered in a single dose either intramuscularly two hours before the operation or intravenously at induction or in a short-term regimen which involves further injections at 12 and 24 hours after surgery ${ }^{3}$. But in most centres in our country, we administer antibiotics for longer duration about 7-10 days. In this study, it has been tried to compare the outcome of short-term use of prophylactic antibiotics with that of traditional long duration use in elective surgery and thus to identify the appropriate schedule of antibiotic prophylaxis in our country and thereby to reduce the cost of antibiotic use, their side effects as well as minimizing the incidence of drug resistance.

\section{Methods:}

A prospective study was designed and done in different surgical units of Mymensingh Medical College Hospital, Mymensingh, from January to December 2005. Patients admitted within that period for elective surgical operations in different surgical units of Mymensingh Medical College Hospital were included in this study. However, among the patients, those who were suffering from severe malnutrition, systemic disease like diabetes mellitus, uraemia, jaundice, patients of malignancy or patients receiving steroid/cytotoxic therapy were not included in this study. In this study, 100 patients have been selected randomly irrespective of their age and sex. Half of the participants (50 cases) received three dose short term antibiotic prophylaxis (designated as short term group) and the rest of half (50 cases) received long term antibiotics for 7 days (designated as long term group).

Second generation of cephalosporin e.g. cefuroxime in parenteral form was used for short-term prophylaxis $-1^{\text {st }}$ dose during induction followed by $2^{\text {nd }}$ and $3^{\text {rd }}$ dose after 8 and 24 hours respectively after operation. In long-term group, both parenteral and oral forms were used. Second generation cephalosporin e.g. cefuroxime was selected for the study because it has both gram positive and negative coverage, ideal for elective surgical prophylaxis ${ }^{3}$.

Relevant data from each subject on his/her clinical ground, per-operative, postoperative and microbiological findings were recorded in a predesigned clinical study sheet. Analysis of the data was done by using SPSS version 11.0.

\section{Preoperative preparation}

Every patient was evaluated clinically by junior surgeons under strict supervision of the unit head for the whole period of hospital stay. All routine and diagnostic investigations as far as possible were done. Preoperative urine culture and sensitivity test was done in all urinary cases. Informed consent was taken from all patients. First dose of parenteral cefuroxime in intravenous form was injected after induction of anaesthesia.

\section{During Operation}

After anaesthesia and positioning skin was cleaned with $10 \%$ povidone-iodine. All incisions were made in such a way so that it gave a good view of the deeper part of the operative field. The skin was cut clearly at one stroke throughout the whole length. Superficial and deep fascial layers were incised in the same way. Proper haemostasis was done with diathermy coagulation. Sometimes catgut was used to ligate the bleeding vessels. 
Standard technique was adopted to close different types of incisions in layers. A drain tube or saline set was used, wherever indicated. At the end of the operation, wound was cleaned with dilute chlorhexidine and methylated spirit soaked sterile swab. Wound was covered with sterile surgical dressing.

\section{Postoperative period}

In short-term group, further doses of prophylactic antibiotics were given after 8 and 24 hours after the operation. Long-term group received injectable cefuroxime 8 hourly and when feasible, oral cefuroxime 12 hourly. Duration was for 7 days. During postoperative period dressings were left undistured upto $5^{\text {th }}$ postoperative day until it was felt necessary to check. Check dressing was done on $5^{\text {th }}$ postoperative day. When dressing was found to have soaked, the wound was examined. A swab was taken from any discharge and sent for bacteriological examination. Wound exposed and explored by removing few sutures for established/suspected infection, subsequently dressed regularly sometimes using povidoneiodine or EUSOL soaked gauze, whenever required for chemical desloughing. Stitches of healthy wounds were removed after 8-10 days postoperatively.

\section{Results:}

The patient population of 100 patients consisted of 66 men and 34 women. The average age of the patients was 35 years. 50 patients had received 3 dose antibiotics during and after operation. Among them 5 cases developed wound infection. Another 50 patients had received antibiotics for 7 days. Among them 6 cases developed wound infection. The average surgical time was 70 minutes. The average length of hospital stay was 7 days. In short-term antibiotic prophylaxis group, there were 5 postoperative wound infections of the 50 patients for an overall infections rate of $10 \%$ (Table-I). In long-term antibiotic prophylaxis group, there were 6 wound infections of the 50 patients for an overall infection rate of $12 \%$ (Table-II). Chi-squired test showed there was no difference between the two group of infection rate $(p<0.001)$. The duration of hospital stay in most of the cases (45 cases) was less than 7 days in short term group and in most of the cases (47 cases) in long duration antibiotic prophylaxis group was more than 7 days (TableIII).

Table-I

Rate of wound infection among patients received short-term antibiotic prophylaxis

\begin{tabular}{llccc}
\hline Indication & $\begin{array}{l}\text { Name of } \\
\text { operation }\end{array}$ & $\begin{array}{c}\text { No. of } \\
\text { operation }\end{array}$ & $\begin{array}{c}\text { No. of } \\
\text { infection }\end{array}$ & $\begin{array}{c}\text { Percentage } \\
\text { of infection }\end{array}$ \\
\hline $\begin{array}{l}\text { Chronic cholecystitis with } \\
\text { cholelithiasis }\end{array}$ & $\begin{array}{l}\text { Open cholecystectomy } \\
\text { Laparoscopic cholecystectomy }\end{array}$ & 5 & 1 & 10 \\
Fibroadenoma of breast & Excision and biopsy & 3 & 0 & 0 \\
Hydrocele & Jaboulay's operation & 3 & 0 & 0 \\
Gastric Outlet Obstruction & Bilateral truncal vagotomy with & 9 & 1 & 11.11 \\
due to pyloric stenosis & gastrojejunostomy & & & 0 \\
Inguinal hernia & Herniotomy with herniorrhaphy & 5 & 0 & 0 \\
Benign Prostatic Hyperplasia & Milin's prostatectomy & 6 & 2 & 33.33 \\
Peripheral vascular disease & Lumber sympathectomy & 4 & 0 & 0 \\
Renal calculi & Nephrolithotomy & 5 & 1 & 20 \\
\hline Total & & 50 & 5 & 10 \\
\hline
\end{tabular}


Table-II

Rate of wound infection among patients received long-duration antibiotic prophylaxis

\begin{tabular}{llccc}
\hline Indication & Name of operation & $\begin{array}{c}\text { No. of } \\
\text { operation }\end{array}$ & $\begin{array}{c}\text { No. of } \\
\text { infection }\end{array}$ & $\begin{array}{c}\text { Percentage } \\
\text { of infection }\end{array}$ \\
\hline Chronic cholecystitis with & Open cholecystectomy & 9 & 1 & 11.11 \\
cholelithiasis & Laparoscopic cholecystectomy & 6 & 0 & 0 \\
Fibroadenoma of breast & Excision and biopsy & 4 & 0 & 0 \\
Hydrocele & Jaboulay's operation & 2 & 0 & 0 \\
Gastric Outlet Obstruction & Bilateral truncal vagotomy with & 10 & 1 & 10 \\
due to pyloric stenosis & gastrojejunostomy & & & \\
Inguinal hernia & Herniotomy with herniorrhaphy & 6 & 0 & 0 \\
Benign Prostatic Hyperplasia & Milin's prostatectomy & 4 & 1 & 25 \\
Peripheral vascular disease & Lumber sympathectomy & 5 & 1 & 20 \\
Renal calculi & Nephrolithotomy & 5 & 2 & 40 \\
\hline Total & & 50 & 6 & 12 \\
\hline
\end{tabular}

Table-III

Duration of hospital stay with short or long term use of prophylactic antibiotics.

\begin{tabular}{lcc}
\hline Duration & \multicolumn{2}{c}{ No. of cases } \\
\cline { 2 - 3 } & $\begin{array}{c}\text { Short-term } \\
\text { antibiotic } \\
\text { prophylaxis }\end{array}$ & $\begin{array}{c}\text { Long-duration } \\
\text { antibiotic } \\
\text { prophylaxis }\end{array}$ \\
\hline Less than 7 days & 45 & 3 \\
More than 7 days & 5 & 47 \\
\hline
\end{tabular}

\section{Discussion:}

Antibiotic prophylaxis has profound role in minimizing postoperative wound infection along with other factors like patient's general condition, age, asepsis, antisepsis, proper sterilization and disinfection methods adopted in wards and operation theatre ${ }^{11}$. Prophylactic antibiotics given empirically during or prior to surgery should be in high dose of broad spectrum with appropriate microbiological sensitivity. Single dose or three-dose regimen is usually followed ${ }^{12}$. But in most centres of our country, prophylactic antibiotics are used for longer duration, for about 7-10 days, which not only costs much more money but also gives rise to different postoperative morbidity and drug resistance ${ }^{13}$. Different workers in this field have given their own opinions on appropriate use of prophylactic antibiotics. In the present study, out of 50 cases of short-term group, 5 developed postoperative wound infection, where as, among 50 cases who got long duration antibiotics, 6 developed wound infection. The overall infection rate is $10 \%$ and $12 \%$ for short term and long-term antibiotic prophylactic group respectively. Therefore, short-term three dose prophylactic antibiotic is adequate for elective surgical operations.

In this study, rate of wound infection in different age group, rate of infection in different elective surgical operations, in different incisions, in different surgical wounds, duration of hospital stay, duration of operation and post-operative adverse effects with short and long term antibiotic prophylaxis were carried out along with bacteriological study in infected cases. The findings of the present study can be compared with that of Zahid et al. ${ }^{14}$; Gul et al. ${ }^{15}$; McDonald et al. ${ }^{16}$; Mathew et al. ${ }^{17}$ published in different journals.

In this series, the rate of wound infection in different age group was studied. Postoperative wound infection is more prevalent in elderly patients than the younger age in both short and long term group. Therefore, age is an important factor in postoperative wound infection as immunity to infection declines with increasing age ${ }^{18}$. 
The rate of wound infections is more in lower abdominal incisions e.g. lower midline, pfannenstiel incision than upper abdominal incisions. The causes of this variation in addition to type of surgery are due to increased bacterial count in adjacent pubic, external genitalia and perineal region ${ }^{19}$.

There is a relation between the length of the operating time and infection rate. In this series the rate of wound infection was less in operations taking less than one hour in comparison to those more than one hour. The possible explanations are dosage of bacterial contamination increases with time, wounded tissues are damaged by drying and by exposure to air and retraction. Longer procedures are more liable to be associated with blood loss and shock; thereby reducing general resistance of the patients ${ }^{20}$.

Wound infection rate varies according to the type of operation- clean, clean-contaminated, contaminated and dirty ${ }^{1}$. In the study rate of wound infection is $0 \%, 12.8 \%$ and $0 \%$ in clean, clean- contaminated and contaminated surgery respectively in patients received three dose antibiotics. On the other hand, the infection rates were $9.09 \%, 12.8 \%$ and $0 \%$ respectively in patients who received long duration prophylactic antibiotics. So there is no added value of using long-term antibiotics in different types of surgery.

Average stay in the hospital is less than 7 days in patients who received short-term prophylactic antibiotics. But hospital stay is more than 7 days in most of the cases who received long-term antibiotics. So this study reveals long-term antibiotics prolongs the hospital stay of the patients.

In the present study, postoperative adverse effects like nausea, vomiting, loose motion, skin rash etc were more experienced by the patients who got long-term antibiotics than those who received only three doses of prophylactic antibiotics.

In this series, Escherichia coli was the most common pathogen cultured from the infected wounds in both group of patients.

\section{Conclusion:}

The role of prophylactic antibiotics in surgical practice is well documented ${ }^{21}$. Antibiotics given just before or during operations reduce the rate of postoperative wound infections. But it is not an alternative to good surgical practice which include strict asepsis, antisepsis, disinfection and sterilization technique. This study shows short term three dose of prophylactic antibiotic is as effective as long-term use of antibiotics traditionally practiced in many centres of our country in elective surgery. The short-term regimen is less costly for the patients, has the same prophylactic benefits and devoid of adverse effects usually experienced by the patients after taking antibiotics for longduration. There is no advantage in prolonging a patient's hospital stay following elective surgery to administer postoperative antibiotics for long duration. So this study recommends short-term three doses of prophylactic antibiotics in elective surgery provided strict asepsis, antisepsis, sterilization and disinfection methods are properly maintained in wards as well as in the operation theatre.

\section{References:}

1. Leaper DJ. Wound infection. In: Russell RCG, Williams NS, Bulstrode CJK. eds. Bailey's and Love short practice of surgery. $23^{\text {rd }}$ ed. London: Arnold; 2000. p.87-90.

2. Nichols RL. Surgical wound infection. Am J Med 172: 455-649.

3. Davis M, Assem ESK. Infection and antibacterial drugs. In: Laurence DR, Bennett PN. eds. Clinical Pharmacology. $7^{\text {th }}$ ed. Edinburgh: Churchill Livingstone; 1993. p.159-61.

4. Davies A, Kibbler C. Reinvention of infection in surgical practice. In: Kirk RM, Mansfield AO. eds. Clinical surgery in general. Edinburgh: Churchill Livingstone; 1999. p.211-3.

5. Cuschieri A, Steele RJC. Patients undergoing elective surgery. In: Moossa AR, Steele RTC, Cuschieri A. eds. Essential surgical practice. $4^{\text {th }}$ ed. Oxford: Butterworth-Heinemann; 2001. p.371-3.

6. Al-Fallouji MAR. ed. General principles and practice in surgery. In: Postgraduate Surgery. $2^{\text {nd }}$ ed. Oxford: Butterworth; 1998. p.88-9.

7. McMinn RMH. Abdomen. In: Sinnatamby CS. ed. Last's anatomy: regional and applied. $10^{\text {th }} \mathrm{ed}$. Edinburgh: Churchill Livingstone; 1994. p.215-20. 
8. Bird AG. The body's defence against infection. In: Walter JB, Talbot IC. eds. General pathology. $7^{\text {th }}$ ed. Edinburgh: Churchill Livingstone; 1996. p.137-41.

9. Samuelson J, Lichtenberg FV. Inflammation and repair. In: Kumar V, Abbas, Fausto. eds. Robbins and Cotran's pathologic basis of disease. $5^{\text {th }}$ ed. WB Saunders; 1994. p.51-9.

10. Leaper DJ. Wound infection. In: Russell RCG, Williams NS, Balstrode CJK (ed) Short Practice of surgery, London, Arnold, 2000; $23^{\text {rd }}$ ed, 94.

11. Davidson BR, Bhattacharya S. Preoperative preparation for surgery. In: Kirk RM, Mansfield AO. eds. Clinical surgery in general. $3^{\text {rd }}$ ed. Edinburgh: Churchill Livingstone; 1999. 171-4.

12. Classer DC, Evans RS, Pestonik SL. The timing of prophylactic administration of antibiotics and risk of surgical wound infection. N Engl J Med 1992; 172: 282-6.

13. Rasul G, Ashraf SA. The role of routine anti-biotic in the prevention of wound infection after surgery. Bangladesh Med Res Counc Bull 1979; 5: $71-4$.

14. Zahid MA, Bakhsh R, Dar FS. Comparison of single dose and three dose antibiotic prophylaxis in cholecystectomy. J Ayub Med Coll. Abboltabad 2003; 15(1): 38-40.

15. Gul YA, Lian LH, Jabar FM, Moissinac K. Antibiotic prophylaxis in clective colorectal surgery. Aust NZ J Surg 2002; 72(4): 275-8.

16. McDonald M, Grabsch E, Marshall C. Single versus multiple dose antimicrobial prophylaxis for major surgery: a systemic review. Aust NZ J Surg 1998; 68(6): 388-96.

17. Mathew A, Dobzyniak MD, Jeffery S, Harry N. Single versus multiple dose antibiotic prophylaxis in lumber disc surgery. J Neuro Surg 2003; 43: 727-31.

18. Cruse PJE, Frood R. The epidemiology of wound infection. Surgical Clinics North America 1980; 60(1): 27-40.

19. Davidson ALG, Clark C, Smith G. Postoperative wound infection. Br J Surg 1971; 43: 58-63.

20. Downey MS, Lamy CJ. Post-operative infections, general principles and considerations. $\mathrm{Br} \mathrm{J}$ Surg 1990; 172: 405-16.

21. Pavel A, Smith RL, Ballard A. Prophylactic antibiotics in elective surgery; a prospective study of 1591 cases. South Med J 1977; 70: 150-5. 